\title{
Effect of Educational Facilities and Infrastructure in Primary Schools on Students' Learning Outcomes
}

\author{
Nugrahana Fitria Ruhyana ${ }^{\otimes 1}$ \& Ani Nur Aeni² \\ ' Bappelitbangda, Kabupaten Sumedang, Indonesia \\ 2 Prodi PGSD Sumedang, Universitas Pendidikan Indonesia, Bandung, Indonesia \\ $\triangle$ nugrahana@gmail.com
}

\begin{abstract}
This research aims at identifying the effect of educational facilities and infrastructure in primary schools on the students' learning outcomes. This was based on the data from the Education Data Centre (Dapodik - Data Pokok Pendidikan) of 2017/2018 Academic Year, indicating that high level of damage to educational facilities and infrastructure, particularly classrooms, and suboptimal students' learning outcomes indicated by a high number of grade retention. This research employed a quantitative method using logistic regression as the data analysis technique. The dependent variable in this research was the students' learning outcomes, while the independent variables were the classroom, teacher toilet, student toilet, library, school-based management, and double shift system. The research population consists of 599 primary schools in Sumedang listed in the District Dapodik 2017. The results indicated that classroom, school-based management, and double shift system had an effect on the students' learning outcomes; meanwhile, library, teacher toilet, and student toilet had no effect on the students' learning outcomes.
\end{abstract}

Keywords: facilities, infrastructure, learning outcomes, primary schools.

How to Cite: Ruhyana, N., \& Aeni, A. (2019). Effect of Educational Facilities and Infrastructure in Primary Schools on Students' Learning Outcomes. Mimbar Sekolah Dasar, 6(1), 43-54. doi:http:// dx.doi.org/10.17509/mimbar-sd.v6il.15225.

INTRODUCTION There are several factors that can affect learning outcomes, which can be grouped into external and internal factors (Bandono \& Samino, 2015; Hamalik, 2011; Mahmud, 2001; Slameto, 2010; Syah, 2013). The external factors include educational facilities and infrastructure. Educational facilities are the facilities that directly support the education process to achieve educational goals, e.g. classroom, book, library, and laboratory. Meanwhile, educational infrastructure is the facilities that indirectly support the education process, e.g. a school garden and schoolyard (Burhanuddin, 2005; Mulyasa, 2011).
While it is true that educational facilities and infrastructure contribute to the factors of successful learning, the data from the Education Data Centre (Dapodik - Data Pokok Pendidikan) of 2017/2018 Academic Year (Kemendikbud, 2017a) indicated a high level of damage to educational facilities and infrastructure, particularly classrooms, and suboptimal students' learning outcomes indicated by a high number of grade retention. These still occur in many regions, thus the efforts to improve the learning effectivity of primary school students and to reduce the psychological burden of repeaters 
Nugrahana Fitria Ruhyana \& Ani Nur Aeni, Effect of Educational Facilities and Infrastructure...

(students undergoing grade retention) are

required.

Table 1. Dapodik Data of Primary School Level in 2017/2018 Academic Year.

\begin{tabular}{llll}
\hline Type(s) & \multicolumn{2}{c}{ School Status } & Total \\
\cline { 2 - 3 } & Public & Private & 148,244 \\
\hline Schools & 563 & 1,594 & $4,257,224$ \\
New students & $3,662,152$ & 595,072 & $25,486,506$ \\
Students & $22,153,241$ & $3,333,265$ & $1,485,602$ \\
Teachers & $1,301,097$ & 184,505 & $1,115,194$ \\
Study groups & 872,110 & 143,084 & $1,072,136$ \\
Classrooms & 930,825 & 141,311 & $4,115,553$ \\
Alumni & $3,660,568$ & 454,985 & 370,116 \\
Repeaters & 334,631 & 35,485 & 32,127 \\
Dropouts & 27,059 & 5,068 &
\end{tabular}

Source: National Dapodik of 2017/2018 Academic Year.

In 2017/2018, the repeaters consisted of $67.46 \%$ female students and $32.54 \%$ male students. Additionally, based on the data in Table 1, there were more repeaters in public schools than in private schools.

Table 2. Numbers of Primary Schools' Classrooms Based on the Condition in 2017/2018 Academic Year.

\begin{tabular}{lll}
\hline Condition & Number & $\%$ \\
\hline Good & 283,109 & 26.41 \\
Lightly damaged & 600,207 & 55.98 \\
$\begin{array}{l}\text { Moderately } \\
\text { damaged }\end{array}$ & 81,601 & 7.61 \\
$\begin{array}{l}\text { Heavily } \\
\text { damaged }\end{array}$ & 63,128 & 5.89 \\
$\begin{array}{l}\text { Completely } \\
\text { damaged }\end{array}$ & 44,091 & 4.11 \\
$\begin{array}{l}\text { Total } \\
\text { Source: National }\end{array}$ & $1,072,136$ & 100 \\
$\begin{array}{l}\text { Academic Years. } \\
\text { capodik of }\end{array}$ & $2017 / 2018$ \\
\end{tabular}

Based on the data in Table 2, the percentage of good classrooms was smaller than the damaged classrooms (lightly, moderately, heavily, and completely), which collectively took 75.59\%. In other words, there were more damaged classrooms than good classrooms. The results of the research conducted by Dardiri (2012) indicate that the damage in the classrooms of primary schools in Malang City affected wallcoverings (plastering) (60.8\%), floors (60.20\%), ceiling hangers (37.5\%), doors/windows (25\%), ceiling covers (21.88\%), ceiling (18.75\%), foundations (3.64\%), and columns and beams (2.20\%). The damage to educational facilities and infrastructure indicated that the conditions of these buildings' infrastructure were bad. These findings are corroborated by Kodoatie in Mahfud (2015) who highlight the fact that Indonesia ranks $12^{\text {th }}$ in the infrastructure quality ratings in Asia after China, the Philippines, Hongkong, Japan, South Korea, Malaysia, Singapore, Thailand, Taiwan, and Vietnam.

Referring to Table 1 and 2, it can be interpreted that educational facilities affect students' learning outcomes, which were indicated by the numbers of repeaters. This indication is supported by the research findings of Puspitasari (2016) and Djamarah \& Zain (2008) stating that "everyone will agree that educational facilities and infrastructure will determine one's success." 
According to previous research, educational facilities and infrastructure are parts of the determinants of students' learning outcomes. However, the effect of specific educational facilities and infrastructure on the learning outcomes has not been studied yet. Therefore, this research aims at identifying the types of facilities and infrastructure in primary schools that strongly affect students' learning outcomes with the indicators proxied by the number repeaters. It is important for policymakers or stakeholders in the education sector to be given specific inputs related to the improvement of facilities and infrastructure in order to improve the quality of education services, especially in the level of primary schools.

Based on the 2017 Dapodik data, out of the total of 599 primary schools, 100 schools still had grade retention. Moreover, the conditions of the facilities and infrastructure in the primary schools were generally poor since there were 98 schools with heavily damaged classrooms, including more than three completely damaged classrooms, which can consequently disrupt the learning process. Some schools addressed this issue by implementing a double shift system, or morning and afternoon classes.

Another kind of damaged educational facilities in Sumedang Regency is library. Only $21 \%$ of libraries were in good conditions in the 599 primary schools and as many as 14 schools did not even have libraries because they were completely damaged. Similarly, the conditions of the educational infrastructure were poor; there were 85 primary schools in Sumedang District with damaged toilets. This condition can disrupt students' overall concentration and school cleanliness.

On another note, the application of School-Based Management (MBS Manajemen Berbasis Sekolah) is significant to be studied because 56 primary schools have not applied MBS yet. Considering the high number of repeaters and an inadequate condition of primary school infrastructure in Sumedang Regency, it is necessary to study this issue by identifying the kinds of educational facilities and infrastructure in primary schools that affect students' learning outcomes.

\section{METHODS}

This research employed a quantitative method to identify the effect of some independent variables related to educational facilities and infrastructure on a dependent variable of students' learning outcomes proxied by repeaters in the grade retention system. A quantitative method was chosen to identify the casual comparative relationship between the independent variables and the dependent variable (Juliandi, Irfan, \& Manurung, 2014).

This research was conducted in September 2018 in Sumedang Regency. The data were obtained from the 2017 Dapodik data, which sourced by the Sumedang Regency Education Office. The Dapodik 
Nugrahana Fitria Ruhyana \& Ani Nur Aeni, Effect of Educational Facilities and Infrastructure...

data were used as the research instruments that were processed using the STATA 14 software. The research population consisted of 599 primary schools in Sumedang Regency based on the 2017 Dapodik data. The research design is depicted in the following figure.

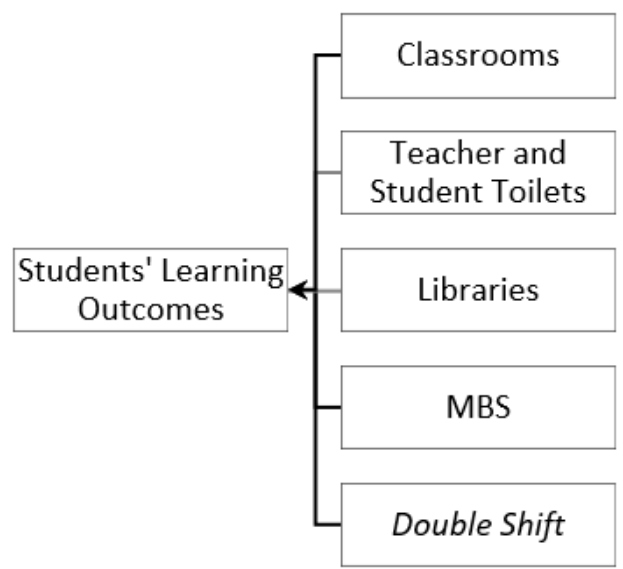

Figure 1. Research Design.

Logistic regression was employed to analyze the data. It is a type of regression that relates one or several independent variables and a dependent variable with the category; usually 0 and 1. Ghozali (2016) explains that logistic regression analysis is similar to discriminant analysis, but both of them have a difference on the type of dependent variable, which is a binary variable ( 1 or 0 ).

The dependent variable was students' learning outcomes proxied by repeaters in the grade retention system based on the 2017 Dapodik data, which was expressed by 1 if there were repeaters, and 0 if there were no repeater. Meanwhile, the independent variables include classroom, teacher toilet, student toilet, library, MBS, and double shift system, which were expressed as follows.

Table 3. Independent Variables.

\begin{tabular}{|c|c|}
\hline damaged_classroom & $\begin{array}{l}1 \text { if there were } \\
\text { damaged } \\
\text { classrooms } \\
0 \text { if there were no } \\
\text { damaged } \\
\text { classroom }\end{array}$ \\
\hline damaged_teacher_toilet & $\begin{array}{l}1 \text { if there were } \\
\text { damaged teacher } \\
\text { toilets } \\
0 \text { if there were no } \\
\text { damaged teacher } \\
\text { toilet }\end{array}$ \\
\hline damaged_student_toilet & $\begin{array}{l}1 \text { if there were } \\
\text { damaged student } \\
\text { toilets } \\
0 \text { if there were no } \\
\text { damaged student } \\
\text { toilet }\end{array}$ \\
\hline damaged_library & $\begin{array}{l}1 \text { if there were } \\
\text { damaged libraries } \\
0 \text { if there were no } \\
\text { damaged library }\end{array}$ \\
\hline Mbs & $\begin{array}{l}1 \text { if the school } \\
\text { applied MBS } \\
0 \text { if the school did } \\
\text { not apply MBS }\end{array}$ \\
\hline double_shift & $\begin{array}{l}1 \text { if the school } \\
\text { applied a double } \\
\text { shift system } \\
0 \text { if the school did } \\
\text { not apply a double } \\
\text { shift system }\end{array}$ \\
\hline
\end{tabular}

Source: Data Processing Results of the 2017 Dapodik Data in Sumedang District.

According to the research variables, the research model is

$Y_{i \text { (repeated) }}=\beta_{0}+\beta_{1}$ damaged_classrooms

$+\beta_{2}$ damaged_teacher_toilets $+\beta_{3}$ damaged_student_toilet + $\beta_{4}$ damaged_libraries $+\beta_{5} \mathrm{mbs}+$ $\beta_{6}$ double_shift $+U$

\section{RESULTS}

Based on the data processing, the results are as follows:

Table 4. Data Processing Results of Independent Variables. 


\begin{tabular}{lll}
\hline Variable(s) & $\begin{array}{l}\text { Coef } \\
\text { logit }\end{array}$ & $\begin{array}{l}\text { Marginal } \\
\text { effect }\end{array}$ \\
\hline damaged_classroom & $0.466^{*}$ & $0.063^{*}$ \\
damaged_teacher_toilets & -0.376 & -0.051 \\
damaged_student_toilets & -0.059 & -0.008 \\
damaged_libraries & -0.666 & $-0.078^{*}$ \\
mbs_ & $-0.583^{*}$ & -0.079 \\
double_shift & $0.530^{* *}$ & $0.072^{* *}$ \\
chi2 & $13.19^{* *}$ & $13.19^{* *}$ \\
\# of obs & 599 & 599 \\
\hline${ }^{*}$ p<0.1, **p<0.05, ***p<0.01 & \\
\hline Source: Data Processing Results of the 2017 \\
Dapodik data in Sumedang District.
\end{tabular}

Table 4 presents that with ceteris paribus assumption, the results showed that schools that had damaged classrooms increased the students' chance of repeating a grade by $6.3 \%$ compared to schools that did not have damaged classrooms. Schools that had applied MBS decreased the students' chance of repeating a grade by $7.9 \%$ compared to schools that had not applied MBS. Schools that had applied a double shift system increased the students' chance of repeating a grade by $7.2 \%$ compared to schools that had not applied a double shift system. Damage of the other facilities and infrastructure (teacher toilet, student toilet, and library) did not affect students' chance of repeating a grade.

\section{DISCUSSION}

\section{Classroom}

The research results indicated that schools that had damaged classrooms had a higher chance of students to repeat a grade compared to schools that did not have damaged classrooms. In other words, the classroom affected students' grade retention. It also meant that the classroom affected the students' learning outcomes. This is in line with the research conducted by Jones (2016) stating that classroom overcrowding was often considered a critical cause of poor learning outcomes in Uganda.

According to Mulyasa (2008), learning outcomes are overall students' achievement that serves as the competency indicators and the degree of their behavioral changes. This was supported by Sudjana (2009) who opines that learning outcomes cover a broad sense, including the cognitive, affective and psychomotor domains. Anggraini \& Untari (2014) explain that learning outcomes are changes in students' behaviors based on their experience in interacting with the environments. Slameto (2010) adds that learning outcomes are influenced by internal and external factors.

Classroom is an external factor that, in this research, was found to have an effect on students' learning outcomes. Similarly, research conducted by Hapnita, Gusmareta \& Rizal (2017) found that the most dominant factor that affected students' learning outcomes was the external factor; $48.87 \%$ affected by internal factors and $51.01 \%$ affected by external factors $(43.3 \%$ of family aspect, $31.57 \%$ of school aspect, and $24.96 \%$ of community aspect).

Classroom as an external factor could affect students' learning outcomes. Students were able to concentrate and be comfortable with the learning if they were in a classroom with a good condition. On 
Nugrahana Fitria Ruhyana \& Ani Nur Aeni, Effect of Educational Facilities and Infrastructure...

the contrary, if the classroom was damaged, it could increase the students' learning anxiety, in addition to be uncomfortable and not concentrate on learning. This anxiety comes from the possible danger caused by the damage in the classroom, such as the possibility of the ceiling to collapse. Therefore, a good condition of the classroom is necessary to improve the students' learning outcomes. If classrooms are in bad condition, the government must take immediate action to fix them so as not to allow the damage to hamper the learning process.

\section{Teacher Toilet}

Table 3 shows that the damaged teacher toilet did not affect the students' chance to repeat a grade. It meant that the condition of damaged teacher toilet did not affect the students' learning outcomes. This result was different from the condition of the damaged classroom that affected students' learning outcomes, which was very reasonable because the condition of the classroom was more closely related to the students as their place of learning. Students who learned in a classroom with a good condition would feel comfortable and this feeling tended to increase the students' concentration in learning. Similarly, teachers who taught in a classroom with a good condition would feel comfortable and tended to concentrate more when teaching, thus improving the quality of learning.

The same thing did not apply to teacher toilet because it is only used by teachers and not directly related to the teaching process. However, even though the teacher toilet did not affect students' learning outcomes, it is considered as an important facility in schools for health reasons.

One influential aspect of school health is sanitation, and toilets are included in sanitation aspect. Based on the data of Kemendikbud (2017b), around 25,835 schools or $12 \%$ of all the schools in Indonesia did not have any toilet. Nationally, only 1 out of 3 primary schools had proper and separate toilets. The rest of the primary schools in Indonesia had proper toilets but not separated, have separate toilets but not in a proper condition, or did not have proper nor separate toilets. This is in line with the research conducted by Saputra (2016) in which it revealed that the availability of toilets in $52.6 \%$ of primary schools in Ungaran Baran District, Semarang Regency did not fulfill the requirements.

The conditions were different in other regions, for instance in Bantul, according to Feryasari (2015), $76.27 \%$ of public primary schools in Jetis District, Bantul Region, had fulfilled the requirements of cleanliness, safety, and completeness of toilet facilities. In some schools, the conditions of teacher toilets were usually much better and cleaner than student toilets. This was in line with Relisa (2016) who states that teacher toilets are cleaner than student toilets because they are always locked, thus not making them 
accessible to just about anyone to keep the toilets clean. In comparison, student toilets can be used by all of the students, thus the higher level of difficulty to maintain the cleanliness.

\section{Student Toilet}

Similar to teacher toilet variable, student toilet did not affect students' learning outcomes because the condition of student toilet was not directly related to the learning process. However, student toilet is still considered as an important facility in schools for health reasons.

In reality, one out of two schools in Indonesia did not have separate toilets for male and female students, with the ratio of 1:122 for male students, and 1:117 for female students (Kemendikbud, 2017b). While the availability of toilet is important, it is also important not to dismiss the students' behaviors in maintaining the cleanliness of the toilet. According to Wokas (2018), based on the research conducted in an elementary school in Sukoharjo, the availability of toilets was sufficient, but the students' behaviors in maintaining the cleanliness need to be improved. Every student needs to have a sense of caring to maintain toilets in schools and get used to healthy living by maintaining the cleanliness of toilets. For instance, as an attempt to have clean and healthy toilets, the students should always flush after using the toilets, rinse the floor when needed, put their trash in the trash can, and keep the water container and tap clean.
Even though those behaviors might seem trivial, they actually require an effort to get accustomed to. Students have to be given the directions on how to keep clean and be aware of the environment, in this case, the awareness of maintaining the cleanliness of the toilet, because it is closely related to their health and comfort; if toilets are clean, they would feel comfortable to use it, and it could also be healthy.

\section{Library}

The results showed that the library did not affect students' learning outcomes that would lead to grade retention. This was different from the research conducted by Hidayat (2018), which found that the higher the library utilization of students, the higher students' learning outcomes. This was in line with Noreng, Masturi \& Utomo (2013) who found that there was an effect of library utilizations on the students' learning outcomes in social studies subject in a junior high school in Pontianak with a very strong correlation coefficient. This was also supported by Nurhayani, Sudarmiatin \& Sunaryanto (2017) who stated that there was a direct effect of library utilization on the positive and significant learning outcomes in social studies subject.

In this research, the existence of libraries did not have an effect on students' learning outcomes because they have not been optimally utilized, especially because of the digital era that allows easier access to digital devices, resulting in the interest in reading to decrease. The same thing is 
Nugrahana Fitria Ruhyana \& Ani Nur Aeni, Effect of Educational Facilities and Infrastructure...

true for library management. The suboptimal management of libraries keeps them from being the source of knowledge; the source where learning materials could be found.

Obstacles in managing libraries were found in the research conducted by Ma'sum, (2015) in an elementary school in Klaten Regency. They include improper facilities of building and rooms, limited book collection, incomplete tools and equipment, lack of parent support, and limited support from the government.

Similar conditions occurred in other regions, according to Bramasta \& Irawan (2017), where the condition of facilities and infrastructure of libraries in primary schools had not fulfilled the standard set by the government in the Regulation of the Ministry of National Education No. 24 of 2007 on June, $2^{\text {th }} 2007$ regarding Facilities and Infrastructure Standards of Public Education Schools.

The library of some schools still had an insufficient collection of books, books that did not support the school subjects, uncomfortable reading rooms, insufficient equipment, and insufficient maintenance. Even, there was a school that did not have a library specifically, in which the library was combined with the teacher room. The poor condition of libraries raised an important concern in the effort to improve the quality of education because libraries are important and inseparable from the quality of schools and education.
Therefore, it is necessary to ensure sufficient book collection in libraries since books are a source of knowledge.

Moreover, students must be motivated by teachers in order to have a high reading interest, so that they will be willing to utilize the library. A good library with sufficient book collection is no use without students' interest in reading, especially reading the book collection in the library.

Based on the research conducted by Triatna (2016), the factors that affected students reading interest can be categorized into internal and external factors. Internal factors comprised feeling, attention, and motivation. The internal factor could be supported by giving motivation and attention continuously to students so that their reading interest can be improved. Meanwhile, the external factors that affected students' reading interest include teachers, the environment, families, and facilities. To improve the students' reading interest, teachers must be able to motivate them, for instance by doing a literacy movement activity by reading for 15 minutes every day or giving a reward to students who visit the library the most in a week and those who successfully finish reading a book in a week.

The family also plays a role in improving students' reading interest. Therefore, teachers should cooperate with parents to control students' reading activities in their homes. In addition, students need to be 
provided with many books in their homes to increase the odd. Additionally, it would be ideal to provide facilities to help increase their interest, such as reading room facilities.

Students in primary schools were more interested in reading illustrated books. They did not get bored and tired when reading those books, because the illustrations were more attractive for them compared to fulltext books. Furthermore, students were also more interested in reading full-color books compared to colorless books, and they would also linger in the reading rooms if the condition was comfortable and fun. Therefore, libraries and reading rooms need to be well-designed in order to make students linger and feel comfortable to read. In addition to the availability of chairs and tables for reading, it would be better to provide a reading room that has a clean carpet with cushions and short tables. Comfortable and clean libraries and reading rooms could increase students reading interest.

\section{School-Based Management}

The results showed that schools that applied Students-Based Management (MBS) had a higher chance of reducing the number of repeaters in the grade retention system. This result is acceptable since MBS is a strategy to improve the quality of education by giving full authority to the school in decision making, thus the principal, teachers, and parents have more control over the learning process (Umaedi, Hadiyanto, \& Siswantari, 2009)
This was in line with the research conducted by Hanafiah (2015), which found that students' learning outcomes in a senior high school in Bireven could be improved by implementing the MBS program. According to Sulaiman, Hasmiana, \& Asmaini (2015), the implementation of MBS can improve the quality of school education because schools are given more authority to manage the education based on the school potential and needs. In addition, schools are given the authority to manage available resources, so the independence and creativity of the school are required in managing the education. Moreover, since schools have to collaborate closely with the community and the government, it is important for the school to be held accountable for their big responsibilities.

Based on the authority and autonomy of the school in management, the principal as the highest leader of the school has been given the flexibility to determine the most beneficial policies for the school, which should still be discussed with teachers and parents' representatives as a part of the community. This was in line with Suhardan (2010) who states that "SchoolBased Management is a management model that provides schools with the autonomy to make a participatory decision that directly involves all school participants in accordance with the service standards of central, provincial, and regional government." 
Nugrahana Fitria Ruhyana \& Ani Nur Aeni, Effect of Educational Facilities and Infrastructure...

The school-based management could encourage the improvement of the quality of education. As stated by Masino \& Zarazua (2016), a factor that can support the improvement of the quality of education is by using "bottom-up and topdown participatory and community management strategies, via decentralization reforms, and with the involvement of communities in the school system management." In implementing its implementation, the role and professionalism of the principal are very important.

\section{Double Shift System}

The results showed that students in schools with a double shift system had a high chance of grade retention. This means that the double shift system affected the students' learning outcomes. This was in line with the research conducted by Sriyanto (2016) stating that students' comprehension skill in afternoon classes was lower than those in morning classes due to exhaustion, sleepiness, and lack of concentration, which were caused by lower teachers' productivity in teaching afternoon classes due to a heavier physical burden.

Hamid (2017) notes that there were 15 thousand primary schools, 11 thousand junior high schools, and 500 senior high schools implementing a double-shift system.

\section{CONCLUSION}

From the explanation above, it can be concluded that classroom, school-based management, and double shift system had an effect on the students' learning outcomes, while library, teacher toilet, and student toilet had no effect on the students' learning outcomes.

Based on these findings, the following recommendations are offered to the Government of Sumedang Regency, especially the Education Office. In order to improve primary school students' learning outcomes and reduce the number of repeaters in the grade retention system, educational facilities and infrastructure need to be improved, especially the classrooms. They must be made comfortable and conducive for the learning process and fulfil the requirements to accommodate the students' needs so that schools do not have to use a double shift system. In addition, it is expected that all primary schools are encouraged and facilitated to apply school-based management.

\section{REFERENCES}

Anggraini, C., \& Untari, M. (2014). Keefektifan Model Permainan BoyBoyan Terhadap Hasil Belajar Tema "Diriku" Siswa Kelas I SD. Mimbar Sekolah Dasar, 1 (1), 92-98.

Bandono, W. A., \& Samino. (2015). Pengelolaan Sarana Dan Prasarana Di Sekolah Dasar Negeri 01 Tohudan, Karanganyar. Profesi Pendidikan Dasar, 2(1), 41-48.

Bramasta, D., \& Irawan, D. (2017). Persebaran Saran dan Prasarana Perpustakaan Sekolah Dasar Berbasis 
Sistem Informasi Geografis. Jurnal Ilmiah Kependidikan: Khazanah Pendidikan, 11 (1), 39-67.

Burhanuddin, Y. (2005). Administrasi Pendidikan. Bandung: Pustaka Setia.

Dardiri, A. (2012). Analisis Pola, Jenis, Dan Penyebab Kerusakan Bangunan Gedung Sekolah Dasar. Teknologi Dan Kejuruan, 35(1), 71-80.

Djamarah, \& Zain, A. (2008). Strategi Belajar Mengajar. Jakarta: Rineka Cipta.

Feryasari, I. (2015). Pemeliharaan Sanitasi Di Sekolah Dasar Negeri SeKecamatan Jetis Kabupaten Bantul. Universitas Negeri Yogyakarta.

Ghozali, I. (2016). Aplikasi Analisis Multivariete Dengan Program IBM SPSS 23 (8th ed.). Semarang: Badan Penerbit Universitas Diponegoro.

Hamalik, O. (2011). Proses Belajar Mengajar. Jakarta: Bumi Aksara.

Hamid. (2017). Kemendikbud: Tahun Depan Sekolah Tidak Ada Double Shift. Retrieved January 28, 2019, from http://www.netralnews.com/news/pe ndidikan/read/86342/kemendikbudtahun-depan-sekolah-tidak-ada-idouble-shift-i-

Hanafiah. (2015). Pelaksanaan Manjgemen Berbasis Sekolah dalam Meningkatkan Hasil Belajar Siswa di SEkolah Menengah Atas Negeri 3 Bireveun Kabupaten Biruen. Universitas Terbuka. Retrieved from http://repository.ut.ac.id/6417/1/42447 .pdf

Hapnita, W, A., Gusmareta, E., \& Y, Rizal, F. (2017). Faktor Internal Dan Eksternal Yang Dominan Mempengaruhi Hasil Belajar Menggambar Dengan Perangkat Lunak Siswa Kelas XI Teknik Gambar Bangunan Smk N 1 Padang Tahun 2016/2017. Cived Jurusan Teknik Sipil, 5(1), 2175-2182.

Hidayat, W. (2018). Hubungan Antara Pemanfaatan Perpustakaan Sekolah Dan Kemandirian Belajar Dengan Hasil
Belajar Siswa Kelas Xi Jurusan Teknik Kendaraan Ringan Smk Negeri 2 Klaten. Universitas Negeri Yogyakarta. Retrieved from http://eprints.uny.ac.id/10534/1/JURN AL PENELITIAN.pdf.

Jones, S. (2016). How does classroom composition affect learning outcomes in Ugandan primary schools? International Journal of Educational Development, 48, 66-78. https://doi.org/10.1016/j.ijedudev.2015 .11 .010

Juliandi, A., Irfan, \& Manurung, S. (2014). Metodologi Penelitian Bisnis. Medan: UMSU Press.

Kemendikbud. (2017a). Ikhtisar Data Pendidikan dan Kebudayaan. Jakarta: Sekjen Pusat Data dan Statistik Pendidikan dan Kebudayaan.

Kemendikbud. (2017b). Profil Sanitasi Sekolah Tahun 2017. Jakarta: Kementerian Pendidikan Dan Kebudayaan Pusat Data Dan Statistik Pendidikan Dan Kebudayaan.

Ma'sum, M. H. (2015). Pengelolaan Perpustakaan Sebagai Sumber Belajar Di SDNegeri 1 Pogung Kecamatan Cawas Kabupat. Jurnal Pendidikan Guru Sekolah Dasar, 3(4), 1-10.

Mahfud. (2015). Manajemen Pemeliharaan Bangunan Gedung Sekolah (Studi Kasus Gedung SLTA di Balikpapan). Jurnal Sains Terapan, 1(1), 7-18.

Mahmud, D. (2001). Psikologi Suatu Pengantar. Jakarta: Dependikbud.

Masino, S., \& Zarazua, M. N. (2016). What works to improve the quality of student learning in developing countries? International Journal of Educational Development, 48, 53-65. https://doi.org/10.1016/j.ijedudev.2015 .11 .012

Mulyasa. (2008). Menjadi Guru Profesional Menciptakan Pembelajaran Kreatif dan Menyenangkan. Bandung: Remaja Rosdakarya. 
Nugrahana Fitria Ruhyana \& Ani Nur Aeni, Effect of Educational Facilities and Infrastructure...

Mulyasa, E. (2011). Manajemen Berbasis Sekolah; Konsep, Strategi dan Implementasi. Bandung: Remaja Rosdakarya.

Noreng, I., Masturi, S. ., \& Utomo, B. B. (2013). Pengaruh Pemanfaatan Perpustakaan Sekolah Terhadap Hasil Belajar IPS Siswa SMP Negeri 18 Pontianak. Jurnal Pendidikan Dan Pembelajaran, 2(3). Retrieved from http://jurnal.untan.ac.id/index.php/jp $\mathrm{dpb/article/view/1404}$

Nurhayani, Sudarmiatin, \& Sunaryanto. (2017). Pengaruh Pemanfaatan Perpustakaan Terhadap Prestasi Belajar IPS Melalui Motivasi Belajar. Jurnal Pendidikan, 2(11), 1443-1449.

Puspitasari, W. D. (2016). Pengaruh Sarana Belajar Terhadap Prestasi Belajar IImu Pengetahuan Sosial Di Sekolah Dasar. Jurnal Cakrawala Pendas, 2(2), 105120.

Relisa. (2016). Kajian Prasarana Pendidikan Sekolah Dasar Sebagai Salah Satu Indikator Pencapaian Standar Nasional Pendidikan. Jurnal Pendidikan Dan Kebudayaan, 1(1), 81-95.

Saputra, J. (2016). Studi Deskriptif Sanitasi Kantin Dan Fasilitas Sanitasi Dasar Di Lingkungan Sekolah Dasar Pada Wilayah Kerja Puskesmas Ungaran Kecamatan Ungaran Barat, Kabupaten Semarang Tahun 2016. Universitas Negeri Semarang.

Slameto. (2010). Belajar dan Faktor-Faktor yang Mempengaruhi. Jakarta: Rineka Cipta.

Sriyanto, H. (2016). Dampak Pembelajaran Gitir Ganda di Sekolah Menengah Umum. Jurnal Ilmu Pendidikan, 6(1), 43-50.

Sudjana, N. (2009). Penilaian Hasil Proses Belajar Mengajar. Bandung: Remaja Rosdakarya.

Suhardan. (2010). Supervisi Profesional. Bandung: Alfabeta.

Sulaiman, Hasmiana, \& Asmaini. (2015). Implementasi Manajemen Berbasis Sekolah (MBS) Dalam Meningkatkan Profesionalisme Guru Di SD Negeri 10 Banda Aceh. Jurnal Pesona Dasar, $3(3), 33-43$.

Syah, M. (2013). Psikologi Pendidikan. Bandung: Remaja Rosdakarya.

Triatna, I. N. (2016). Minat Baca Pada Siswa Kelas VI Sekolah Dasar Negeri Delegan 2 Prambanan Sleman Yogyakarta. E-Jurnal Prodi Teknologi Pendidikan, 5(6), 166-178.

Umaedi, Hadiyanto, \& Siswantari. (2009). Manajemen Berbasis Sekolah. Jakarta: Universitas Terbuka.

Wokas, A. (2018). Gambaran Tentang Perilaku Hidup Bersih Dan Sehat Di Sekolah Dasar Negeri Gumpang 01 Kartasura Sukoharjo. Universitas Muhammadiyah Surakarta. 